\title{
Age-Dependent Expression of 5 $\alpha$-Reductase and Androgen Receptors mRNA by the Canine Prostate
}

\author{
F. SHIDAIFAT \\ Department of Basic Veterinary Medical Sciences, Faculty of Veterinary Medicine, Jordan \\ University of Science and Technology, Irbid, Jordan
}

Received July 23, 2007

Accepted October 8, 2007

On-line January 17, 2008

\begin{abstract}
Summary
The growth of the prostate gland is androgen-dependent. Testosterone is converted to the most potent dihydrotestosterone (DHT) by $5 \alpha$-reductase within the prostate. Androgen interacts with androgen receptors (AR) to regulate normal growth of the prostate and has also been implicated in both the progression of benign prostate hyperplasia and prostate cancer. This study was conducted to compare the mRNA expression of AR and $5 \alpha-$ reductase by the prostate gland from three age categories: immature, young-mature and old dogs. Quantitative gene expression was assessed by the real-time PCR and the results were expressed as a relative mRNA expression of the target gene. This study revealed that there was no significant difference in the mRNA expression of the AR gene by the prostate gland of immature, young and old dogs. In contrast, there is a highly significant $(P<0.001)$ down-regulation in $5 \alpha$-reductase gene by the prostate of young and old dogs as compared with immature dogs. However, there is no significant difference in mRNA expression of the $5 \alpha$-reductase gene by the prostate gland from young and old dogs. This differential expression of AR and $5 \alpha-$ reductase genes, which are involved in the regulation of androgen effect on prostate gland, might reflect an agedependent growth requirement of the gland for androgens.
\end{abstract}

\section{Key words}

Prostate $\bullet$ Androgen receptors $\bullet 5 \alpha$-reductase $\bullet$ Canine

\section{Corresponding author}

F. Shidaifat, Associate professor of Veterinary Physiology, Faculty of Veterinary Medicine, Jordan University of Science and Technology, Irbid-Jordan. E-mail: falah@just.edu.jo
Continuous supply of androgen is a prerequisite for driving the prostate gland growth and for maintaining its steady-state size. Androgen has also been implicated in the progression of prostatic diseases, such as benign prostate hyperplasia (BPH) and prostate cancer. Although testosterone is the prevalent circulating androgen, dihydrotestosterone (DHT) is the most active androgen involved in the regulation of the prostate gland. The conversion of testosterone to its active metabolite is achieved through the activity of $5 \alpha$-reductase, which occurs in two isozymes, type I and type II. While the type II predominantly is expressed by prostatic cells, type I is expressed by other tissues, such as skin and liver. Deficiency of type II but not type I severely impeded the prostate gland development in human and to a lesser extent in rats (Imperato-Mcginley and Zhu 2002, Carson and Rittmaster 2003, Mahendroo et al. 2001). Therefore, inhibitors of $5 \alpha$-reductase, which were used as therapeutic agents for the treatment of $\mathrm{BPH}$, resulted in a significant reduction in the prostate gland size (Tarter and Vaughan 2006, Cohen et al. 1995, Laroque et al. 1995).

Androgen exerts its effect on prostate gland development through the interaction with androgen receptor (AR). $A R$ acts as a transcription factor that regulates the expression of androgen response genes that are involved in many cellular activities that ranges from proliferation to programmed cell death (So et al. 2003). AR expression level has been shown to increase in close association with the continuous growth of the dorsal and lateral lobes of the prostate gland in some rat strains which develop an age-dependent spontaneous hyperplasia 
(Banerjee et al. 2001). In contrast, AR expression level has been shown to decrease in the ventral lobe of the gland, which exhibited age-dependent growth senescence (Banerjee et al. 2001). Androgen removal studies in rats also revealed a rapid regression of the ventral lobe of the prostate gland by inducing epithelial cell apoptosis (Perlman et al. 1999, Banerjee et al. 2000, Banerjee et al. 2002) but not in the dorsolateral lobes (Banerjee et al. 2002). In addition, AR expression has been shown to be associated with cell proliferation and survival of prostate cancer and it might contribute to prostate cancer progression (Amirghofran et al. 2004). These results demonstrate clearly the importance of androgen receptor expression level in regulating the rates of prostate gland growth and senescence.

Dogs are known to develop an age-dependent spontaneous prostate hyperplasia (Brendler et al. 1983). Although this process is androgen-dependent, the expression of genes that are involved in the regulation of androgen action, such as AR receptor and $5 \alpha$-reductase, are not well established. Therefore, this study was designed to compare the mRNA expression levels of AR and $5 \alpha$-reductase (Type II) genes by the prostate gland in immature, young and aged dogs.

To conduct this experiment, twelve male dogs were divided into three age groups: immature, youngadult and old-adult dogs. Each group had 4 dogs. The immature dogs were about 1 month of age, the young dogs were about two years old, and the old dogs were between 6-8 years of age. After the dogs were euthanized by intravenous injection of $10 \%$ thiopentone sodium, the prostate glands were removed and stored in liquid nitrogen for subsequent RT-PCR analysis. The protocol of animal handling and euthanasia were approved by the Jordan University of Science and Technology Animal Care and Use Committee (JUST-ACUC).

Total RNA was extracted from the frozen prostate gland using an SV Total RNA isolation kit (Promega Corporation, Madison, WI, USA). The RNA concentration was determined by measuring the absorbance at $260 \mathrm{~nm}$ using SmartSpec ${ }^{\mathrm{TM}}$ Plus spectrophotometer (Bio-Rad, Hercules, CA, USA). $0.5 \mu \mathrm{g}$ of total RNA was used to synthesize a complementary DNA (cDNA) using the reverse transcription kit (Promega Corporation, Madison, WI, USA). The RT reaction was carried out at $25{ }^{\circ} \mathrm{C}$ for $5 \mathrm{~min}$ followed by $42{ }^{\circ} \mathrm{C}$ for $60 \mathrm{~min}$ and then at $95{ }^{\circ} \mathrm{C}$ for $5 \mathrm{~min}$. The samples were then placed on ice for $5 \mathrm{~min}$ and stored at $-20{ }^{\circ} \mathrm{C}$ for PCR amplification.

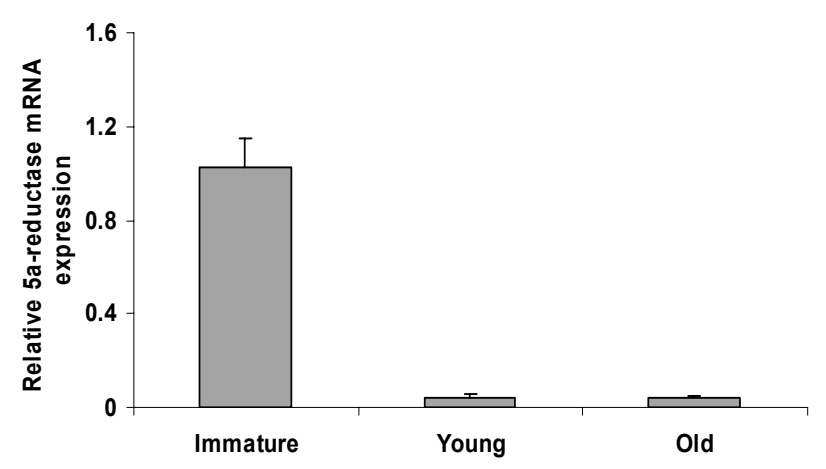

Fig. 1. Relative mRNA expression of 5a-reductase type II by the prostate gland from immature, young-adult dogs and old-adult dogs. Each bar represents the mean \pm S.E.M. of 4 dogs. Bars with different letters represent means that are significantly different $(P<0.001)$.

Real time PCR analysis was performed using a commercial PCR kit containing sybergreen florescent dye (QuantiTect $^{\mathrm{TM}} \mathrm{SYBR}^{\circledR}$ Green; Qiagen, Valencia, CA, USA) in the presence of $2 \mu \mathrm{M}$ of specific primers. The primers were designed to be specific for the canine sequence using the web-based QuantiProb Design software (QuantiTec Cuatom Assays, www.qiagen.com). The forward sequence for the primer used for androgen receptors was GAG GTA GTA TCA GAA GGT AG and the reverse primer was CTG TCC GAG ATG GTC GAA. The forward primer for $5 \alpha$-reductase type II was ACT CAT TGC TCA CTA GAG G and the reverse primer was CTC AGC GCA GTA AAT CAG A. The forward sequence for glycerolaldehyde-3-phosphate dehydrogenase (GAPDH) primer was CTG GAG AAA GCT GCC AAA and the reverse primer was TGT TGA AGT CAC AGG AGA. The PCR amplification reactions were started with an initial denaturation at $95{ }^{\circ} \mathrm{C}$ for $15 \mathrm{~min}$, followed by 45 cycles each composed of denaturation at $95{ }^{\circ} \mathrm{C}$ for $30 \mathrm{~s}$, annealing at $55{ }^{\circ} \mathrm{C}$ for $30 \mathrm{~s}$ and extension at $72{ }^{\circ} \mathrm{C}$ for $30 \mathrm{~s}$. At the end of the 45 cycles the melting curve for the reactions was performed at temperatures ranging from $72{ }^{\circ} \mathrm{C}$ to $95{ }^{\circ} \mathrm{C}$.

Relative mRNA gene expression was determined using the $2^{-\Delta \Delta C} \mathrm{~T}$ method and normalized to GAPDH expression (Livak and Schmittgen 2001). One-way analysis of variance (ANOVA) of mRNA expression was performed using Minitab software (Minitab Inc.,State College, PA, USA). The results were presented as the mean \pm S.E.M. A probability of less than $0.05(\mathrm{P}<0.05)$ was considered statistically significant. The mRNA expression of each gene was twice analyzed from different pools of total RNA. 


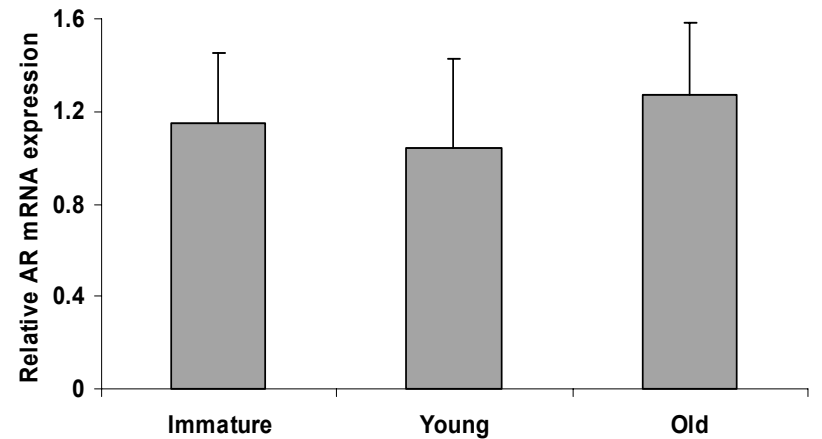

Fig. 2. Relative mRNA expression of androgen receptor by the prostate gland from immature, young-adult and old-adult dogs. Each bar represents the mean \pm S.E.M. of 4 dogs. There were no significant statistical differences between groups $(P>0.05)$.

The results of this study revealed a differential mRNA expression of AR and $5 \alpha$-reductase type II genes by the prostate gland obtained from immature, young and old dogs. As shown in Figure 1, there is a highly $(\mathrm{P}<0.001)$ significant reduction in $5 \alpha$-reductase mRNA expression by the prostate gland from young and old dogs as compared with its expression in prostates of immature dogs. However, there is no significant difference in $5 \alpha$-reductase mRNA expression between young and old prostate glands. It has been shown that inhibition of $5 \alpha$-reductase resulted in a significant decrease of prostate gland volume probably by inducing prostatic cell apoptosis (Laroque et al. 1995, Steers 2001). This reduction in the prostate gland size correlated well with a decrease in DHT and the concomitant increase in testosterone level (Cohen et al. 1995), indicating that DHT rather than testosterone plays a key permissive role in the prostate gland growth and development. It has been shown that the physiological concentration of testosterone is higher in adults as compared to immature dogs (Brendler et al. 1983, Mialot et al. 1988). Therefore, the present results emphasized the importance of $5 \alpha$ reductase as a rate limiting step for the reduction of the effective concentration of testosterone within the prostate gland in young and old dogs and thus should reduce the prostate gland growth. Surprisingly, the canine prostate gland continued its post-maturation growth (Brendler et al. 1983) despite this highly significant inhibition of $5 \alpha$-reductase. One possible explanation for this discrepancy might be due to the fact that DHT is an

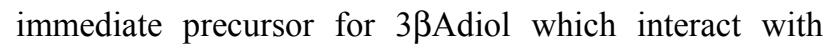
estrogen receptor $\beta$ (ER $\beta)$ and acts as a negative regulator of prostate gland growth. Therefore, the inhibition of $5 \alpha$ reductase would also prevent the formation of $3 \beta$ Adiol and, by doing so, would remove the growth-limiting effect of $\operatorname{ER} \beta$ (Weihua et al. 2002).

In contrast to the expression of $5 \alpha$-reductase, there is no significant difference in AR mRNA expression by prostate gland of immature, young and old dogs (Fig. 2). Androgen receptor expression has been shown to vary in an age- and species-dependent manner. Although AR expression by the ventral lobes of rat prostate shows an age-dependent decrease (Banerjee et al. 2001, Prins et al. 1996), its expression level by young adult and old dogs remained either unchanged (Prins et al. 1996) or increased with age (Niu et al. 2003). This age-dependent and species-specific variation in AR receptor expression appeared to parallel the inherent differential character of age-dependent growth and senescence of the prostate in rats and dogs. While the rat prostate gland growth ceases after maturity, the dog prostate continues to grow as the animal gets older. However, in some rat strains when there is a tendency of the dorsal and lateral lobes of the rat prostate gland to continue its development beyond the mature state, there is a parallel increase in AR expression (Banerjee et al. 2001). Interestingly, the spontaneous and age-dependent development of prostate hyperplasia has been shown to occur despite the decrease of serum testosterone level (Banerjee et al. 1998). Therefore, the increment of AR expression might act to enhance the responsiveness of prostatic cells to androgen stimulation and to compensate for its decline. As the dogs are known to develop an agedependent benign prostate hyperplasia, then the consistent expression level of AR by the dog prostate gland from different ages might be, at least in part, involved in its continuous growth.

In conclusion, the results presented herein demonstrated that the expression level of AR is consistent with the expected age-dependent continuous growth of the prostate gland. The transition of the prostate gland from immature to mature required a dramatic downregulation in $5 \alpha$-reductase expression. Nevertheless, its steady-state expression is required for the post-maturation growth.

\section{Conflict of Interest}

There is no conflict of interest.

\section{Acknowledgements}

This study was supported by the Jordan University of Science and Technology and the World Bank project for higher education development 


\section{References}

AMIRGHOFRAN Z, MONABATI A, GHOLIJANI N: Androgen receptor expression in relation to apoptosis and expression of cell cycle related protein in prostate cancer. Pathol Oncol Res 10: 37-41, 2004.

BANERJEE PP, BANERJEE S, BROWN TR: Increased androgen receptor expression correlates with development of age-dependent, lobe-specific spontaneous hyperplasia of Brown Norway rat prostate. Endocrinology 142: 4066-4075, 2001.

BANERJEE PP, BANERJEE S, BROWN TR: Bcl-2 protein expression correlates with cell survival and androgen independence in rat prostatic lobes. Endocrinology 143: 1825-1832, 2002.

BANERJEE S, BANERJEE PP, BROWN TR: Castration-induced apoptotic cell death in the brown Norway rat prostate decreases as function of age. Endocrinology 141: 821-832, 2000.

BANERJEE PP, BANERJEE S, LAI JM, STRANDBERG JD, ZIRKIN BR, BROWN TR: Age-dependent and lobespecific spontaneous hyperplasia in the brown Norway rat prostate. Biol Reprod 59: 1163-1170, 1998.

BRENDLER CB, BERRY SJ, EWING LL, MCCULLOUGH AR, COCHRAN RC, STRANDBERG JD, ZIRKIN BR, COFFEY DS, WHEATON LG, HILER ML, BORDY MJ, NISWENDER GD, SCOTT WW, WALSH PC: Spontaneous benign prostatic hyperplasia in the beagle. Age-associated changes in serum hormone levels, and the morphology and secretory function of the canine prostate. J Clin Invest 71: 1114-1123, 1983.

CARSON C, RITTMASTER R: The role of dihydrotestosterone in benign prostatic hyperplasia. Urology 61 (Suppl 4A): 2-7, 2003.

COHEN S M, WERRMANN JG, RASMUSSON GH, TANAKA WK, MALATESTA PF, PRAHALADA S, JACOBS JG, HARRIS G, NETT TM: Comparison of the effect of new specific azasteroid inhibitors of steroid 5 alphareductase on canine hyperplastic prostate: suppression of prostatic DHT correlated with prostate regression. Prostate 26: 55-71, 1995.

IMPERATO-MCGINLEY J, ZHU Y-S: Androgen and male physiology the syndrome of $5 \alpha$-reductase-2 deficiency. Mol Cell Endocrinol 198: 51-59, 2002.

LAROQUE PA, PRAHALADA S, MOLON-NOBLOT S, COHEN SM, SOPER K, DUPRAT P, PETER CP, VAN ZWIETEN MJ: Quantitative evaluation of glandular and stromal compartment in hyperplastic dog prostate: effect of 5-alpha reductase inhibitors. Prostate 27: 121-128, 1995.

LIVAK KJ, SCHMITTGEN TH: Analysis of relative gene expression data using real-time quantitative PCR and the $2^{-\Delta \Delta C}$ T. Methods 25: 402-408, 2001.

MAHENDROO MS, CALA KM, HESS DL, RUSSELL DW: Unexpected virilization in male mice lacking steroid 5 $\alpha$-reductase enzymes. Endocrinology 142: 4652-4662, 2001.

MIALOT JP, THIBIER M, TOUBLANC JE, CASTANIER M, SCHOLLER R: Plasma concentration of luteinizig hormone, testosterone, dehydroepiandrosterone, androstenedione between birth and one year in the male dog: longitudinal study and hCG stimulation. Andrologia 20: 145-154, 1988.

NIU YJ, MA TX, ZHANG J, XU Y, HAN R.F, SUN G: Androgen and prostatic stroma. Asian J Androl 5: 19-26, 2003.

PERLMAN H, ZHANG X, CHEN MW, WALSH K, BUTTYAN R: An elevated bax/bcl-2 ratio corresponds with the onset of prostate epithelial cell apoptosis. Cell Death Differ 6: 48-54, 1999.

PRINS GS, JUNG MH, VELLANOWETH RL, CHATTERJEE B, ROY AK: Age-dependent expression of the androgen receptor gene in the prostate and its implication in glandular differentiation and hyperplasia. Dev Genet 18: 99-106, 1996.

SO AI, HURTADO-COLL A, GLEAVE ME: Androgen and prostate cancer. World J Urol 21: 325-337, 2003.

STEERS WD: 5alpha-reductase activity in the prostate. Urology 58: 17-24, 2001.

TARTER TH, VAUGHAN EDJR: Inhibitors of $5 \alpha$-reductase in the treatment of benign prostatic hyperplasia. Curr Pharm Des 12: 775-783, 2006.

WEIHUA Z, LATHE R, WARNER M, GUSTAFSSON J-A: An endocrine pathway in the prostate, ER $\beta$, AR, $5 \alpha$-androstane-3 $\beta, 17 \beta$-diol, and CYP7B1, regulates prostate growth. Proc Natl Acad Sci USA 99: 1358913594, 2002. 